Research Paper

\title{
Development and assessment of a latex agglutination test based on recombinant MSP5 to detect antibodies against Anaplasma marginale in cattle
}

\author{
Carlos A.N. Ramos ${ }^{1}$, Flábio R. Araújo ${ }^{1}$, Rafaelle C. Santos ${ }^{2}$, Elaine S.P. Melo ${ }^{3}$, \\ Letícia C. Sousa ${ }^{3}$, Carlos E.S. Vidal ${ }^{4}$, Neurisvan R. Guerra ${ }^{5}$, Rafael A.N. Ramos ${ }^{6}$ \\ ${ }^{1}$ Embrapa Gado de Corte, Campo Grande, MS, Brazil. \\ ${ }^{2}$ Programa de Pós Graduação em Saúde Animal na Amazônia, Universidade Federal do Pará, \\ Castanhal, PA, Brazil. \\ ${ }^{3}$ Programa de Pós Graduação em Ciência Animal, Universidade Federal de Mato Grosso do Sul, \\ Campo Grande, MS, Brazil. \\ ${ }^{4}$ Programa de Pós Graduação em Medicina Veterinária, Universidade Federal de Santa Maria, \\ Santa Maria, RS, Brazil. \\ ${ }^{5}$ Programa de Pós Graduação em Ciência Animal Tropical, Universidade Federal Rural de Pernambuco, \\ Recife, PE, Brazil. \\ ${ }^{6}$ Department of Veterinary Medicine, Universita degli Studi de Bari, Valenzano, Bari, Italy.
}

Submitted: July 17, 2012; Approved: April 4, 2013.

\begin{abstract}
The recombinant protein MSP5 has been established as an important antigen for serological diagnosis of Anaplasma marginale by enzyme-linked immunosorbent assay (ELISA). However, due to the high cost of specialized equipment, this technique is not accessible to all laboratories, especially in developing countries in areas where the disease is endemic. The present study describes the standardization of a latex agglutination test (LAT) to detect antibodies against $A$. marginale based on recombinant MSP5. Compared with indirect enzyme-linked immunosorbent assay (iELISA), the relative sensitivity and specificity of the LAT were $95.21 \%$ and $91.86 \%$ respectively, with an almost perfect agreement between tests (kappa index $=0.863$ ). These results can be considered important for the serological diagnosis of A. marginale, as they indicate that the test represents a rapid and low cost alternative to ELISA.
\end{abstract}

Key words: latex agglutination, rapid test, Anaplasma marginale, MSP5.

\section{Introduction}

A variety of serological tests, such as the indirect fluorescent antibody test (IFAT) (Lohr et al., 1973), complement fixation (Gainer, 1961), enzyme-linked immunosorbent assay (ELISA) (Luckins, 1977) and more recently, the immunosensor (Silva et al., 2006a) have been used to detect antibodies to A. marginale. However, most of these techniques require equipment and specialized technicians, which increase the reaction costs substantially. Thus, the development of a simpler and less expensive method is desirable for laboratories with little infrastructure, especially in developing countries with areas where the disease is endemic.

In recent years, the major surface protein (MSP) 5 has been established as an important antigen for serological diagnosis of $A$. marginale (Reyna-Bello et al., 1998; Silva et al., 2006a,b; Melo et al., 2007). The use of recombinant antigens in serological assays has favored the development of highly standardized diagnostic tests that are both reproducible and inexpensive (Boonchit et al., 2002).

The aim of the present study was to develop and evaluate a latex agglutination test (LAT) using recombinant MSP5 as antigen to detect antibodies against $A$. marginale in cattle. 


\section{Materials and Methods}

\section{Serum samples source}

All cattle serum samples used in the present study were originally collected for other epidemiological studies between 2005 and 2010, and stored at $-20^{\circ} \mathrm{C}$ at Embrapa Beef Cattle, Campo Grande, MS, Brazil. The sample selection for assessment by serological methods was based on the convenience for researchers and the epidemiological status of the region of origin to A. marginale.

Serum samples were obtained from cattle that had been experimentally infected with $A$. marginale $(\mathrm{n}=48)$ and from cattle kept in a tick-free isolation area of Embrapa Beef Cattle, Campo Grande, MS, Brazil $(\mathrm{n}=50)$. Sera was also obtained from cattle raised in areas of endemic stability of A. marginale: from the Brazilian states of Pará $(\mathrm{n}=71)$, Rio de Janeiro $(\mathrm{n}=66)$ and Mato Grosso do Sul $(\mathrm{n}=76)$ (Souza et al., 2000; Guedes Junior et al., 2008); as well as from cattle raised in areas of endemic instability such as the Brazilian states of Rio Grande do Sul ( $n=153)$ and Pernambuco $(\mathrm{n}=5)$; and Costa Rica $(\mathrm{n}=54)$ in central America (Artiles et al., 1995; Oliveira et al., 2011). Serum samples from cattle experimentally infected with $B$. bovis $(\mathrm{n}=16)$ or B. bigemina $(\mathrm{n}=30)$ and negative for antibodies against $A$. marginale in iELISA and the immunofluorescent antibody test (IFI) were also used.

\section{Recombinant MSP5 production}

Recombinant protein was produced as described by Silva et al. (2006b). Briefly, Escherichia coli TOP10 with pTrc-HisTOPO/msp5 was grown in Luria Bertani (LB) broth supplemented with $100 \mu \mathrm{g} / \mathrm{mL}$ ampicillin. Gene expression was stimulated by $1 \mathrm{mM}$ isopropyl- $\beta$-D-galactopyranoside (IPTG) and incubation for six hours at $37^{\circ} \mathrm{C}$ at $250 \mathrm{rpm}$. E. coli cells were then recovered by centrifugation at $10,000 \mathrm{xg}$ for $10 \mathrm{~min}$, and the recombinant protein was purified in denaturing conditions using the HisTrap HP agarose-nickel resin (GE Healthcare), following the manufacturer's instructions. The purity of rMSP5 was confirmed by sodium dodecyl-polyacrylamide gel electrophoresis (SDS-PAGE) and dialyzed with phosphate saline buffer $\mathrm{pH} 7.2$ (PBS) at $4{ }^{\circ} \mathrm{C}$ for 48 hours. Once the proteins became insoluble after dialysis, solubilization with $2 \%$ SDS was conducted as described by Lechtziee et al. (2002). The protein concentration was determined by SDS-PAGE stained with Coomassie blue by comparison with known concentrations of bovine serum albumin (BSA) using the LabImage v.3.3.2 image analysis software (Loccus, Brazil).

\section{Latex beads/rMSP5 conjugation}

Polystyrene latex particle suspension ( $0.8 \mu \mathrm{m}$ diameter, Sigma LB-8) was diluted to $1 \%$ with phosphate saline buffer (PBS) pH 7.2. The latex particle suspension was centrifuged at $3500 \mathrm{x}$ g for $45 \mathrm{~min}$. After removing the super- natant, the polystyrene latex particles were resuspended to $1 \%$ with previously solubilized rMSP5, diluted in PBS to a final concentration of $0.5 \mathrm{mg} / \mathrm{mL}$. The mixture was incubated for $24 \mathrm{~h}$ at room temperature with constant shaking. After incubation, rMSP5-sensitized latex particles were recovered by centrifugation at $3500 \mathrm{x} \mathrm{g}$ for $45 \mathrm{~min}$, resuspended in PBS with $0.5 \mathrm{mg} / \mathrm{mL}$ of BSA and blocked for one hour at room temperature with constant shaking. The blocked latex particles were washed twice with PBS and centrifuged again at $3500 \mathrm{x}$ g for $45 \mathrm{~min}$. The recovered rMSP5 sensitized latex particles were diluted to $1 \%$ with PBS containing $0.01 \%$ sodium azide, $0.05 \mathrm{mg} / \mathrm{mL}$ of BSA and $5 \%$ of glycerol. The rMSP5 latex agglutination test (rMSP5 LAT) antigen was kept at $4{ }^{\circ} \mathrm{C}$ until use.

\section{rMSP5 latex agglutination test assessment}

The agglutination reactions were performed on black agglutination cards, with antigen and serum at room temperature. The optimal serum/antigen ratio and reaction time were defined by an assessment of three serum samples obtained from cattle kept in a tick-free isolation area of Embrapa Beef Cattle, Campo Grande, MS, and three sera samples from cattle experimentally infected with $A$. marginale. The serum samples used were negative and positive to antibodies against $A$. marginale, respectively, with indirect ELISA (iELISA) with rMSP5 as antigen (Silva et al., 2006b). The selection of optimal parameters was based on naked eye observation of agglutination with positive serum and the absence of agglutination with negative serum. The serum samples were classified only as positive $(+)$ or negative (-).

The relative sensitivity and specificity of the MSP5 LAT were assessed using the iELISA based on rMSP5 (Silva et al., 2006b) as the standard. Five hundred and sixty-nine bovine serum samples were paired-tested with iELISA and the LAT. An additional assessment of the specificity of the rMSP5 LAT was performed with serum samples from cattle experimentally infected with $B$. bovis $(\mathrm{n}=16)$ or B. bigemina $(\mathrm{n}=30)$.

All rMSP5 LAT were performed by a technician without previous information about the status of the sera (positive/negative) as defined by iELISA. This caution was taken to avoid any bias related test interpretation.

\section{Stability and repeatability}

The stability of the rMSP5 LAT antigen was assessed by the agglutination of the standard positive serum with sensitized latex beads stored at $4{ }^{\circ} \mathrm{C}$ for 8 months. The standard sera used were the same as those used in the standardization reaction (serum/antigen ratio and reaction time).

Repeatability was determined by the analysis of 139 serum samples: 66 positive and 73 negative to antibodies against $A$. marginale with iELISA, using three batches of the rMSP5 LAT antigen (B1, B2 and B3), produced from different inductions and purifications of the recombinant 
protein. The serum samples used to assess reproducibility were also selected by convenience. The 139 samples used in this stage of the study were composed of 54 samples from Costa Rica (Central America), 51 samples from the semi-arid of Pernambuco and 34 samples, randomly selected, from Rio Grande do Sul.

\section{Statistical analyses}

The agreement between tests (LAT and iELISA) and batches of antigen (B1, B2 and B3) was assessed by the kappa index and interpreted based on the scale described by Landis and Koch (1977). The significance of differences between the tests were obtained by analysis of discordant results by McNemar's $\chi^{2}$ test. The analyses were realized using the software BioStat 5.0. Differences were considered statistically significant when $\mathrm{p}<0.05$.

\section{Results and Discussion}

The rMSP5 sensitized latex and serum agglutinated in the presence of $A$. marginale antibodies but remained evenly dispersed in the absence of antibodies (Figure 1).
The optimal ratio of serum/antigen and reaction time established was 1:4 $(10 \mu \mathrm{L}$ of serum and $30 \mu \mathrm{L}$ of rMSP5 LAT antigen) and three minutes, respectively. The relative comparison between the rMSP5 latex agglutination test and iELISA also based on rMSP5 (Table 1), previously standardized and validated by Silva et al. (2006b), resulted in an almost perfect agreement $(94.20 \%, 536 / 569)$ with a kappa index of 0.863 (95\% CI $0.818-0.908)$. The relative sensitivity and specificity of the rMSP5 LAT were $95.21 \%$, and $91.86 \%$ respectively. No significant difference was observed between the tests $(p=0.486)$. In the assessment of the analytical specificity of the rMSP5 LAT antigen, agglutination was not observed when serum from cattle that had been experimentally infected by $B$. bovis or B. bigemina was used.

The rMSP5 LAT antigen was stable during the eight months of assessment. All standard samples showed the same result month to month. Although it was not the objective of the present study to assess the agglutination intensity, a slight reduction was observed over the months. This could compromise the sensitivity of the rMSP5 LAT when performed with antigen stored for a long time. Therefore, a
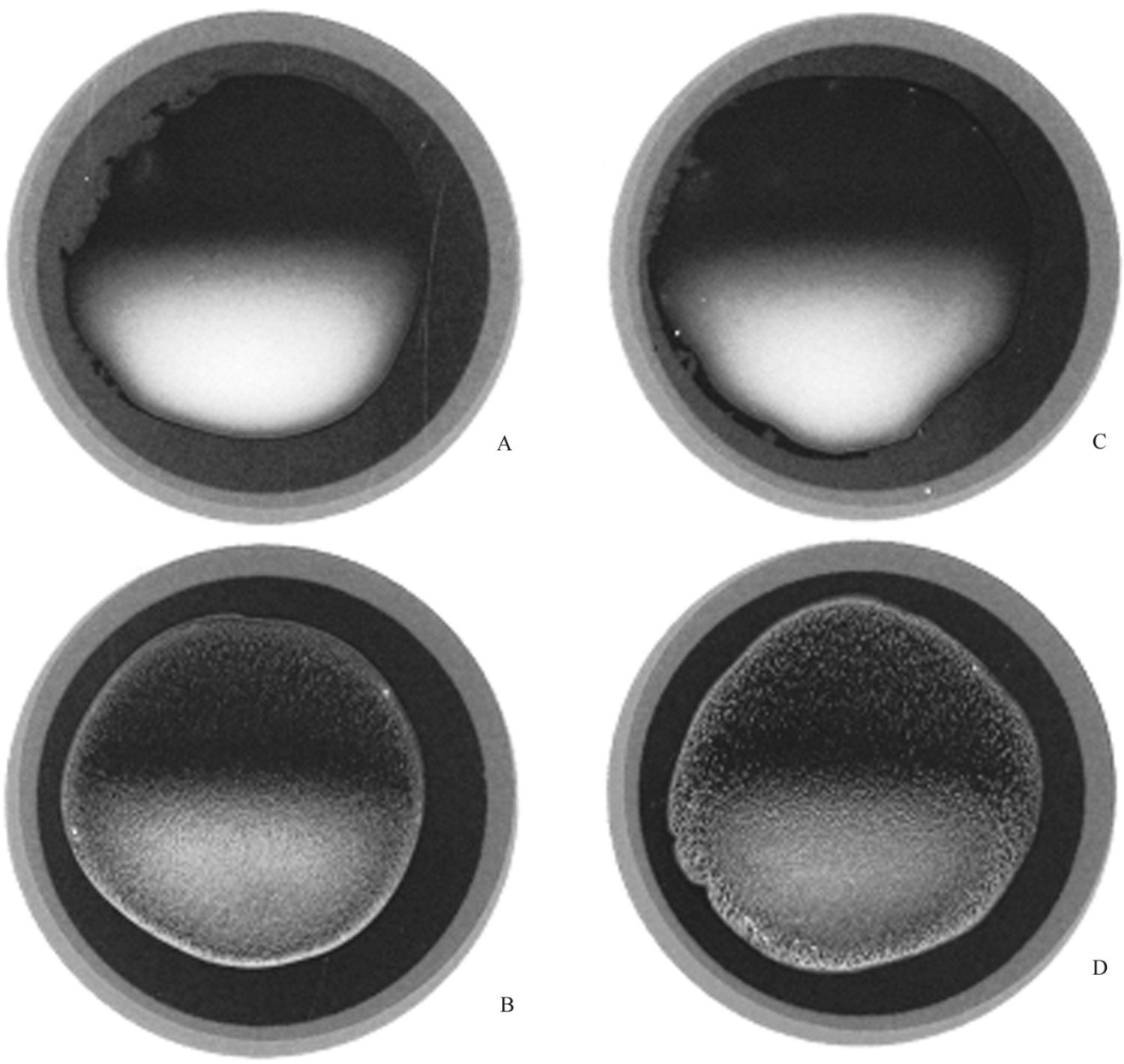

Figure 1 - Latex agglutination test of bovine sera using rMSP5. Anaplasma marginale negative (A, C) and positive sera (B, D) were mixed with latex beads coated with rMSP5. Agglutination is clearly observed in panels B and D. 
Table 1 - Comparison between the results of iELISA and the rMSP5 LAT to detect antibodies against $A$. marginale in cattle.

\begin{tabular}{lccc}
\hline \multicolumn{4}{c}{ iELISA } \\
\hline rMSP5 LAT & Positive & Negative & Total \\
\hline Positive & 378 & 14 & 392 \\
Negative & 19 & 158 & 177 \\
Total & 397 & 172 & 569 \\
\hline
\end{tabular}

more detailed study in relation to LAT antigen stability is necessary. Additional stability assessments of the antigen in other temperature zones were not performed.

The rMSP5 LAT to A. marginale showed good repeatability between three different batches of antigen. There was an agreement between: B1 and B2 of $97.12 \%$ (kappa $0.941,95 \%$ CI $0.885-0.998$ ); B1 and B3 of $97.84 \%$ (kappa $0.956,95 \%$ CI $0.907-1$ ); B2 and B3 of $99.28 \%$ (kappa $0.985,95 \%$ CI 0.956 - 1). The differences found between the batches of antigen were not statistically significant by McNemar $\chi^{2}$ test $(\mathrm{B} 1 \times \mathrm{B} 2 \mathrm{P}=0.125 ; \mathrm{B} 1 \times \mathrm{B} 3$ $\mathrm{p}=0.250 ; \mathrm{B} 2 \times \mathrm{B} 3 \mathrm{p}=1)$.

Comparisons between seroprevalence obtained by the rMSP5 LAT and iELISA in each region (Pará, Rio de Janeiro, Mato Grosso do Sul, Rio Grande do Sul, semi-arid Pernambuco and Costa Rica) are shown in Table 2. No significant differences were observed between tests. According to the concept of enzootic stability/instability proposed by Mahoney and Ross (1972), no differences were observed in region classification based on the results of the rMSP5 LAT or iELISA.

Agglutination tests to detect antibody against $A$. marginale have been used for decades in capillary tubes, cards or plates (Welter, 1964; Amerault and Roby, 1968; Howarth and Hokama, 1976; Rodgers et al., 1998). However, in all cases the A. marginale antigen used is derived from initial body semi-purified from bovine erythrocytes (Wilson et al., 19778) or in vitro propagated in tick cell line (Rodgers et al., 1998). These antigens are formed by a complex protein mixture, making it difficult to standardize dif- ferent batches of antigen, resulting on low reproducibility. In the case of bovine derived antigens, contamination with erythrocytic stroma can contribute to false positive reactions (Barry et al., 1986). In addition, for the production of antigen an experimental infection of cattle is necessary, which increases the production costs and has important ethical implications.

Advances in molecular technologies during the last decade, especially in cloning and gene expression, have enabled the production, with highly reproducible methodologies, of recombinant proteins of a variety of organisms, including A. marginale (Silva et al., 2006b; Araújo et al., 2008). Many of these recombinant proteins have been utilized in serodiagnosis of $A$. marginale with excellent results (Reyna-Bello et al., 1998; Melo et al., 2007).

The latex agglutination test appears attractive, since this test is simple and rapid. In the reaction presented in the present study, no more than three minutes were enough to achieve the result with sensitivity and specificity comparable to the other agglutination test of $A$. marginale (Wilson et al., 1978; Rodgers et al., 1998). An additional advantage is that the test does not require previous serum dilution or reading equipment, such as the semi-automated agglutination developed by Rodgers et al. (1998), nor does it require a long incubation time before reading as is the case of the capillary agglutination test used by Wilson et al. (1978). Furthermore, the LAT does not require bovine serum factor (BSF), unlike the card agglutination assays presented by Amerault and Roby (1968), Howarth and Hokama (1976) and Bastos et al. (2000). Another advantage of the rMSP5 LAT is related to the cost and portability. No special equipment is required to perform the test and thus it can be conducted in the field conditions. In Brazil, the cost of the rMSP5 LAT for each sample tested was estimated to be less than US\$ 0.27.

The false positive result of the rMSP5 LAT (15/597) in relation to iELISA can be attributed to immunoglobulin $\mathrm{M}(\operatorname{IgM})$ reaction, either from cattle recently infected by $A$. marginale or nonspecific binding (Holliman et al., 1989). Since IgM antibodies appear earlier after infection, it in-

Table 2 - Comparison of the seroprevalence to Anaplasma marginale obtained with the rMSP5 LAT and iELISA by region.

\begin{tabular}{lcccc}
\hline Seroprevalence \% (Positive/Total) & & & & \\
\hline Region & rMSP5 LAT & iELISA & p-value ${ }^{\mathrm{a}}$ & $\begin{array}{c}\text { Epidemiological status }^{\mathrm{b}} \\
\text { (rMSP5 LAT/ iELISA) }\end{array}$ \\
\hline Pará/Brazil & $91.54(65 / 71)$ & $90.14(64 / 71)$ & 1.00 & Stability/ Stability \\
Rio de Janeiro/Brazil & $98.48(65 / 66)$ & $100(66 / 66)$ & 1.00 & Stability/Stability \\
Mato Grosso do Sul/Brazil & $97.36(74 / 76)$ & $97.36(74 / 76)$ & 1.00 & Stability/Stability \\
Rio Grande do Sul/Brazil & $60.78(93 / 153)$ & $63.39(97 / 153)$ & 0.45 & Instability/ Instability \\
Pernambuco/Brazil (semi-arid) & $52.94(27 / 51)$ & $45.09(23 / 51)$ & 0.12 & Instability/ Instability \\
Costa Rica (Central America) & $46.29(25 / 54)$ & $42.59(23 / 54)$ & 0.62 & Instability/ Instability \\
\hline
\end{tabular}

${ }^{\mathrm{a}} \mathrm{McNemar} \chi^{2}$ test.

${ }^{\mathrm{b}}$ Classification proposed by Mahoney and Ross (1972). 
duces intense agglutination reactions (Janeway Jr. et al., 2005) and is not detected by iELISA used as standard method. On the other hand, most of the false negative reactions may have been due to the difficulty of identifying weak reactions with the naked eye, or due to the prozone effect (Butch, 2000). Some of these problems could easily be minimized by reading automation and sera dilution. However, the test run would be limited to the laboratory.

To assess the hypothesis of the prozone effect, the nineteen iELISA positive and the rMSP5 LAT negative sera samples were diluted serially in PBS (1:4 to 1:16). Six samples showed agglutination that was visible to the naked eye in the 1:4 dilutions, as well as one sample in the 1:8 dilution. No sample agglutinated at 1:16 dilution.

Currently, it is known that MSP5 as the antigen in serodiagnosis is not specific for $A$. marginale. Cross-reactivity with antibodies against $A$. centrale, $A$. ovis, $A$. phagocytophilum and recently a new genotype of Ehrlichia (BOV2010), have been reported (Dreher et al., 2005; A1Adhami et al., 2011). However, in Brazil other species of the blood-borne bacterial family Anaplasmataceae infecting cattle does not have been described, except occasional reports of $A$. bovis, limited to the state of Rio de Janeiro (Santos and Carvalho, 2006; Melo Junior et al., 2010). Therefore, although it is not possible to affirm that the specificity of the rMSP5 LAT is restricted to A. marginale, in areas in which bovine anaplasmosis is endemic, and other Anaplasmataceae do not occur, is a useful epidemiological tool.

In conclusion, the rMSP5 LAT is a simple and economical technique that can be used in the field and is suitable for epidemiological studies, principally in developing countries where the equipment and technology required for ELISA is not always available. Positive results derived from these assay should be interpreted with caution due to the high degree of conservation of the MSP5 among family Anaplasmataceae.

\section{References}

Al-Adhami B, Scandrett WB, Lobanov VA, Gajadhar AA (2011) Serological cross-reactivity between Anaplasma marginale and an Ehrlichia species in naturally and experimentally infected cattle. J Vet Diagn Invest. 23:1181-1188.

Amerault TE, Roby TO (1968) A rapid card agglutination test for bovine anaplasmosis. J Am Vet Med Assoc. 153:1828-1834.

Araújo FR, Costa CM, Ramos CAN, Farias TA, Souza IIF, Melo ESP, Elisei C, Rosinha GMS, Soares CO, Fragoso SP, Fonseca AH (2008) IgG and IgG2 antibodies from cattle naturally infected with Anaplasma marginale recognize the recombinant vaccine candidate antigens VirB9, VirB10 and elongation factor-Tu. Mem Inst Oswaldo Cruz. 103:186190.

Artiles J, Alves-Branco FPJ, Martins JR, Correa LB, Sapper MFM (1995) Prevalência de Babesia bovis, Babesia bigemina e Anaplasma marginale no município de Bagé, RS. Braz J Vet Parasitol 6:179.
Barry DN, Parker RJ, De Vos AJ, Dunster P, Rodwell BJ (1986) A microplate enzyme-linked immunosorbent assay for measuring antibody to Anaplasma marginale in cattle serum. Aust Vet J. 63:76-79.

Bastos PAS, Madruga CR, Leal CRB, Araújo FR, Germano PML, Garcia M, D'Angelino LL (2000) Evaluation of IFI, ELISA and TCR test in Anaplasma marginale antibodies detection. Braz J Vet Med. 22:125-127.

Boonchit S, Xuan X, Yokoyama N, Goff WL, Wagner G, Igarashi I (2002) Evaluation of an enzyme linked immunosorbent assay with recombinant Rhoptry-associated protein 1 antigen against Babesia bovis for the detection of specific antibodies in cattle. J Clin Microbiol. 40:3771-3775.

Butch AW (2000) Dilutions protocols for detection of Hook effects/Prozone phenomenon. Clin Chem. 46:1719-1720.

Dreher UM, de la Fuente J, Hofmann-Lehmann R (2005) Serologic cross-reactivity between Anaplasma marginale and Anaplasma phagocytophilum. Clin Diagn Lab Immunol. 12:1177-1183.

Gainer JH (1961) Demonstration of Anaplasma marginale with the fluorescent dye, acridine orange: comparisons with the complement-fixation test and Wright's stain. Am J Vet Res. 22:882-886.

Guedes Junior DS, Araújo FR, Silva FJM, Rangel CP, Barbosa Neto JD, Fonseca AH (2008) Frequency of antibodies to Babesia bigemina, B. bovis, Anaplasma marginale, Trypanosoma vivax and Borrelia burdgorferi in cattle from the northeastern region of the state of Pará, Brazil. Braz J Vet Parasitol. 17:105-109.

Holliman RE, Johnson J, Duffy K, New L (1989) Discrepant toxoplasma latex agglutination test results. J Clin Pathol. 42:200-203.

Howarth JA, Hokama Y (1976) The modified card agglutination test: an accurate tool for detecting anaplasmosis in columbian black-tailed deer. J Wildl Dis. 12:427-434.

Janeway Jr CA, Travers P, Walport M, Shlomchik MJ (2005) Immunobiology: the imune system in health and disease, 6nd ed. Garland Science Publishing, New York.

Landis JR, Koch GG (1977) The measurement of observer agreement for categorical data. Biometrics 33:159-174.

Lechtzier V, Hutoran M, Levy T, Kotler M, Brenner T, Steinitz M (2002) Sodium dodecyl sulfate treated proteins as ligands in ELISA. J Immunol Methods. 270:19-26.

Lohr KF, Ross JP, Meyer H (1973) Studies on homologous and heterologous antibody responses to infections with Anaplasma marginale and A. centrale using the indirect fluorescent antibody and capillary tube agglutination tests. Z Tropenmed Parasitol. 24:86-95.

Luckins AG (1977) Detection of antibodies in trypanosomeinfected cattle by means of a microplate enzyme-linked immunosorbent assay. Trop Anim Health Prod. 9:53-62.

Mahoney DF, Ross DR (1972) Epizootiological factors in the control of bovine babesiosis. Aust Vet J. 48:123-128.

Melo ESP, Araújo FR, Ramos CAN, Soares CO, Rosinha GMS, Elisei C, Madruga CR (2007) ELISA com MSP5 recombinante truncada para detecção de anticorpos contra Anaplasma marginale em bovinos. Pesq Vet Bras. 27:301-306.

Melo Junior OA, Albernaz AP, Thiebaut JTL, Miranda FJB, Machado JA, Silva ACF (2010) Ocorrência de Anaplasma bovis (Donatien \& Lestoquard, 1936, Dumler et al., 2001) 
na região de Bom Jesus do Itabapoana, RJ. Ci Anim Bras. 11:888-891.

Oliveira JB, Montoya J, Romero JJ, Urbina A, Soto-Barrientos N, Melo ESP, Ramos CAN, Araújo FR (2011) Epidemiology of bovine anaplasmosis in dairy herds from Costa Rica. Vet Parasitol. 177:359-365.

Reyna-Bello A, Cloeckaert A, Vizcaíno N, Gonzatti MI, Aso PM, Dubray G, Zygmunt MS (1998) Evaluation of an enzymelinked immunosorbent assay using recombinant major surface protein 5 for serological diagnosis of bovine anaplasmosis in Venezuela. Clin Diagn Lab Immunol. 5:259-262.

Rodgers SJ, Saliki JT, Blouin EF, Kocan KM (1998) The development of a semi-automated latex agglutination test for detection of antibodies to Anaplasma marginale using a cell culture derived antigen. Ann N Y Acad Sci. 849:282-292.

Santos CF, Carvalho CB (2006) Primeiro relato de Anaplasma bovis (DONATIEN \& LESTOQUARD, 1936) DUMLER et al. (2001) na microrregião de Campos dos Goytacazes, Estado do Rio de Janeiro, Brasil: nota de pesquisa. Bras J Vet Parasitol. 15:126-127.
Silva M, Wilkowsky S, de Echaide ST, Farber M, Oliva A (2006). Development of an immunosensor for the diagnosis of bovine anaplasmosis. Ann N Y Acad Sci. 1081:379-381.

Silva VM, Araújo FR, Madruga CR, Soares CO, Kessler RH, Almeida MA, Fragoso SP, Santos LR, Ramos CAN, Bacanelli G, Torres RA (2006) Comparison between indirect enzyme-linked immunosorbent assays for Anaplasma marginale antibodies with recombinant major surface protein 5 and initial body antigens. Mem Inst Oswaldo Cruz. 101:511-516.

Souza JCP, Soares CO, Massard CL, Scofield A, Fonseca AH (2000) Soroprevalência de Anaplasma marginale em bovinos na mesorregião Norte Fluminense. Pesq Vet Bras. 20:97-101.

Welter CJ (1964) Serologic stability and specificity of agglutination Anaplasma marginale antigen. Am J Vet Res 25:1058-1061.

Wilson AJ, Trueman KF, Spinks G, McSorley AF (1978) A comparison of 4 serological tests in the detection of humoral antibodies to anaplasmosis in cattle. Aust Vet J. 54:383-386.

All the content of the journal, except where otherwise noted, is licensed under a Creative Commons License CC BY-NC. 